Article

\title{
Geo-Environmental Estimation of Land Use Changes and Its Effects on Egyptian Temples at Luxor City
}

\author{
Abdelaziz Elfadaly ${ }^{1,2,3}$ (D), Osama Wafa ${ }^{4,5}$, Mohamed A. R. Abouarab ${ }^{4}$ (D) , Antonella Guida $^{2}$, \\ Pier Giorgio Spanu ${ }^{5}$ and Rosa Lasaponara ${ }^{1, *}$ \\ 1 Italian National Research Council, C.da Santa Loja, Tito Scalo, 85050 Potenza, Italy; \\ abdelaziz.elfadaly@yahoo.com \\ 2 Department of European and Mediterranean Cultures, Architecture, School of Architecture, \\ University of Basilicata, 75100 Matera, Italy; arch.antonellaguida@gmail.com \\ 3 Department of Population Studies and Archaeology, National Authority for Remote Sensing and Space \\ Sciences, Cairo 1564, Egypt \\ 4 Department of Archaeology, Faculty of Arts, University of Kafrelsheikh, Kafr el Sheikh 1501, Egypt; \\ usama.ibrahim1@art.kfs.edu.eg (O.W.); mabouarab@art.kfs.edu.eg (M.A.R.A.) \\ 5 Department of History, Human Sciences and Training, University of Sassari, 07100 Sardinia, Italy; \\ pgspanu@uniss.it \\ * Corresponding: rosa.lasaponara@imaa.cnr.it; Tel.: +39-328-627-1131
}

Received: 31 August 2017; Accepted: 14 November 2017; Published: 22 November 2017

\begin{abstract}
Over the years, the Egyptian temples at Luxor city have been intensely investigated, but most of these studies just focused on the classical sides of the archaeological and historical descriptions. Many of the environmental problems are the inevitable results of the unplanned urban crawling around the monuments temples. This paper aims at assessing the environmental changes around some temples of Luxor City using remote sensing and GIS techniques. In particular, a historical database made up of Corona and Landsat TM data have been investigated along with the new acquisitions of Quickbird 2 and Sentinel 2. Results from our investigation highlighted rapid changes in urban and agricultural areas, which adversely affected the Egyptian monumental temples causing serious degradation phenomena. Using the information obtained from our RS\&GIS based analysis, mitigation strategies have been also identified for supporting the preservation of the archaeological area.
\end{abstract}

Keywords: environmental risks; satellite data; GIS techniques; Egyptian temples

\section{Introduction}

Recent improvements in earth observation techniques offer advanced technical characteristics, which can enhance new applications including investigations addressed to cultural heritage and landscape. In particular, the most recent missions, such as the ESA sentinel, offer for free data (systematically acquired for the entire globe) and are specifically concerned with risk estimation and monitoring. Moreover, long and rich historical archives (as those available from declassified satellite data, Landsat TM, etc.) provide significant past-related information that can be very useful for changing detection investigations. Both recent and archived data, jointly used, can offer an invaluable source of information for a wide variety of applications, including investigations that are addressed to archaeology and cultural landscapes ranging from the documentation to the enhancement, from the monitoring to the management.

In particular, remote sensing for archaeology has been widely applied for discovery [1-3] and monitoring [4,5] in the Middle East [6] and in Egypt for many application domains, including discovery and documentation [7], and, more recently, conservation and monitoring purposes [8-12]. 
Conservation and protection policies to preserve cultural heritage and landscape is a pressing issue today, especially for sites and areas that significantly represent the cultural identity of a territory, population, country, and civilization. It is important to highlight that archaeological sites, cultural properties, and landscape are "non-renewable resources, and they hold specific cultural values for mankind, that need to be preserved for the present and future generations"; further, it can be added that such "assets are also important economic resources; and, in view of increasing public interest, an organized approach to decision making would assure the conservation and preservation of the various values of the archaeological sites and cultural landscape, including their educational and economic potential" (UNESCO [13,14]).

Recently, many researchers showed that Radar, hyperspectral, and multispectral satellite images can be used to enhance the status of archaeological environments in order to detect subsurface remains. Optical satellite remote sensing has played an important role in the field of archaeological studies over the last years. Reflection of crop and soil vegetation are well-known indicators of the presence of ancient buried and surface remains. Until now, new remote sensing applications have been developed in discovering, monitoring, documenting, and preserving cultural resources. Typically, these techniques have been exploited by means of optical multispectral sensors. On the other hand, remote sensing indicators of land and groundwater can provide useful data where practical classical methods cannot. Integrated remote sensing and GIS are widely used in groundwater mapping, has made them the focal point of many geo-archaeological studies, Starting from aerial photos [15-19].

This paper aims to assess the current status of the temples of Luxor City using Remote sensing and GIS techniques to identify and map areas that are affected by uncontrolled urban expansion and changes in land use that are considered as some of the critical threats for these cultural properties [20,21] (http://whc.unesco.org/en/soc/3597). To quantify over the years the urban sprawling, historical multi-temporal satellite data made up by Corona, Landsat have been investigated along with the new acquisitions provided by Quikbird and Sentinel 2. Results from our multi-date and multi-sensor data analysis provided quantitative information on changes in agricultural areas, as well as on the uncontrolled urban expansion that occurred around the Egyptian monumental cities. Based on the integration of ancillary information with the outputs obtained from Remote Sensing and GIS-based analysis, a mitigation strategy is also herein proposed.

\subsection{Study Area}

Thebes in Luxor, situated about $900 \mathrm{~km}$ south of Cairo around the River Nile banks [22] (Latitude: $25^{\circ} 41^{\prime} 56^{\prime \prime} \mathrm{N}$, Longitude: $32^{\circ} 38^{\prime} 31^{\prime \prime}$ E, Elevation above sea level: $89 \mathrm{~m}$ ) is considered one of the largest, richest, and best-known archaeological sites in the world. The resources accruing made possible a massive building of temples all over the country mainly in the Thebes' great centre where Karnak and Luxor were developed (in the East side) along with the great complexes mortuary (in the West side), which includes the Hatshepsut and Medinet Habu [23] (Figure 1a,b).

\subsection{Luxor City Temples}

\subsubsection{East Luxor City Temples}

Karnak and Luxor temples are recognized to be clear examples of the development and growth of the magnificent Egyptian temples [24]. The great temple of Karnak was dedicated to Amon, the local god of Thebes [25]. During the New Kingdom, a new processional style on the north-south axis was created and are still today evident in the Luxor and Amun temples and in the precinct of Mut to the south. The temples had an impressive hypostyle hall and ten massive pylons that were interspersed with courtyards (the largest hypostyle hall ever built [26]). The roof is supported by 20 columns in two rows and 32 square pillars [27] (Figure 2). The great festival hall, measuring 52 feet in depth and 144 feet in width. 


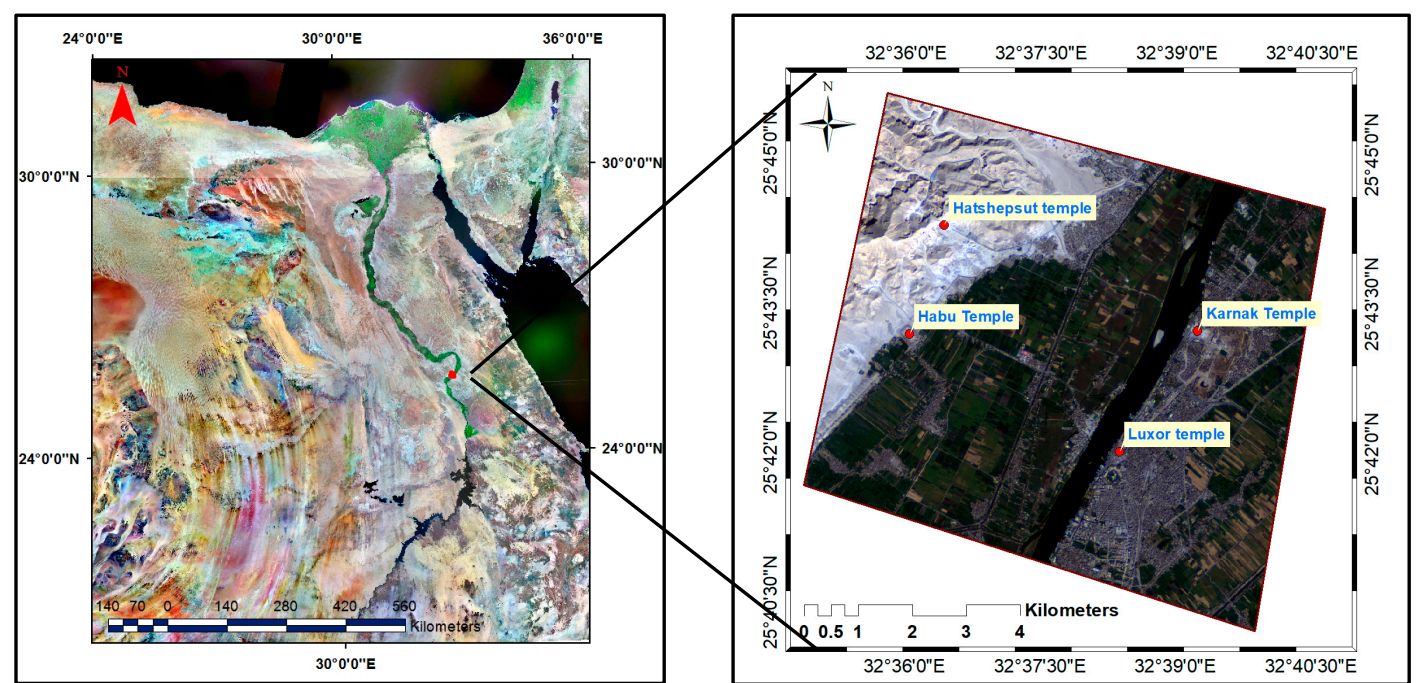

(a)

(b)

Figure 1. Map of Egypt by Landsat 7 (a) and study area by Sentinel-2 11/2016 (Composite RGB 4, 3, 2) (b).

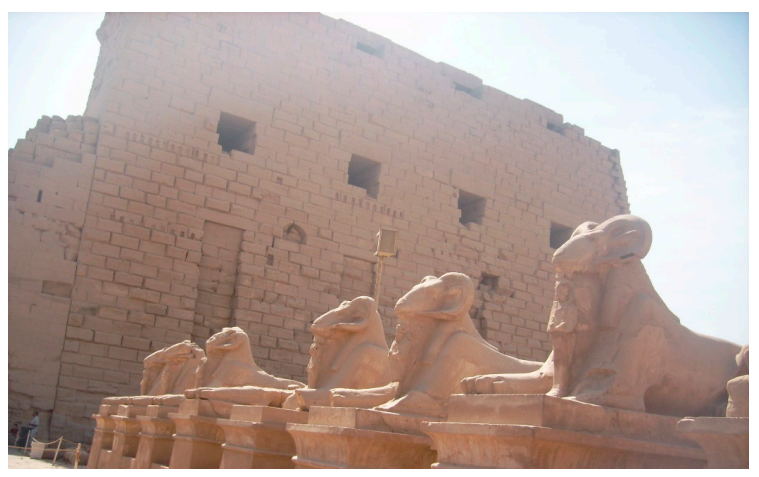

Figure 2. The main façade of Karnak temple at east Luxor.

The design of Luxor temple clearly shows still today the attractive influence it played for its first enormous court out of straight alignment. This space becomes a sloping parallelogram to reach the route from Karnak temple and join it to the axis of the sanctum at Luxor temple [28]. The central doorway gave its access to an eight columned hall, with another direction doorway in the opposite wall. The centre of a castrum, the southern doorway of Luxor temple, was blocked with an apse when the Romans re-used it [29] (Figure 3).

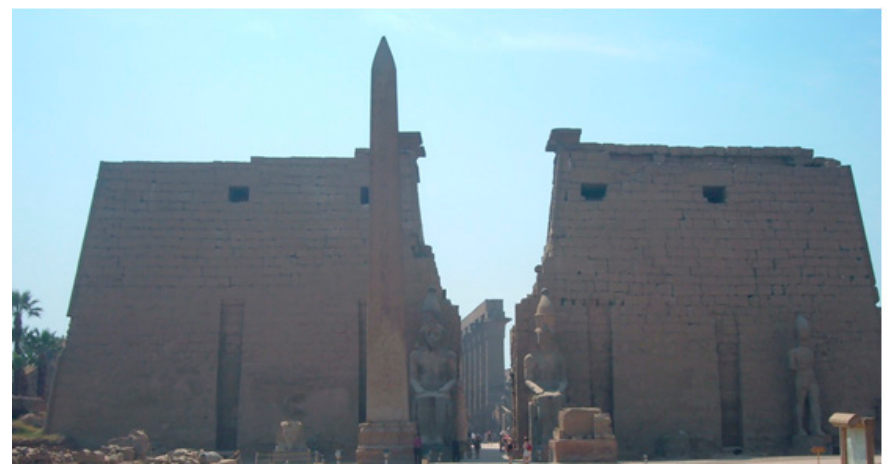

Figure 3. The main façade of Luxor temple at east Luxor. 


\subsubsection{West Luxor City Temples}

Some of the temples in Upper Egypt have a tower above the ancient plain. The best preserved mortuary temple is known as Medinet Habu of Ramses III, and is related to the 20th dynasty and is located in the district on the west bank of the Nile [30]. As the living king at Medinet Habu, the king Ramses III writes upon the walls of the temple: "I built my house-of-millions-of-years for the (Amon) in the Thebes necropolis" [31]. Until now, Medinet Habu as it is now called, still exists as the most famous temples on the west bank of the Nile, and the most extensively constructed of the principle temples of Egypt. The fallen walls, empty rooms, celebrations, and devotions, which once happened there, often give only suggestions of the rituals [32] (Figure 4).

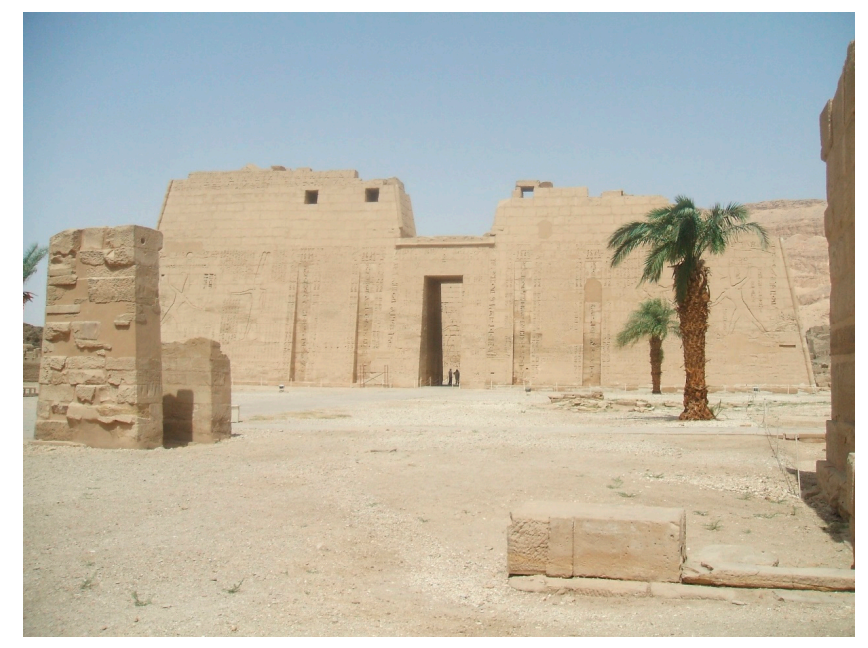

Figure 4. The main façade of Medinet Habu west Luxor.

The tradition of ancient Egyptian buildings often displays a striking harmony with the properties of Egypt's natural environment: the horizontal line, mounds, pyramidal masses of the desert, and rectilinear textures of the cliffs of the Nile Valley. The Mortuary Temple of queen Hatshepsut plays an example of these [33]. The original sanctuary was built by the queen Hatshepsut. There is doubt that the third room of the Sanctuary showed to be a niche, decorated to offer the god Amun. There are enough remains of the niche facade, with representations of the queen Hatshepsut and the king Tuthmosis III on both sides of the entrance, the main sanctuary divide to two rooms and three enormous niches in the second room [34] (Figure 5).

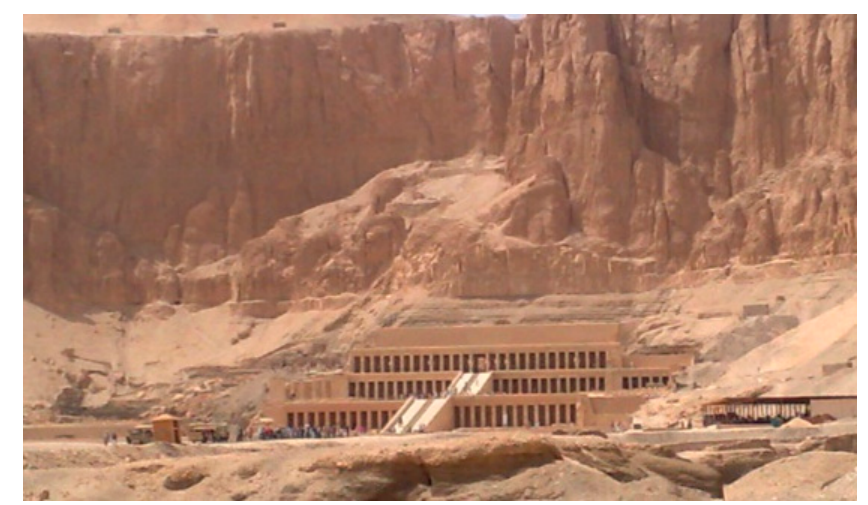

Figure 5. The main façade of Hatshepsut temple at west Luxor. 


\subsection{Environmental Status}

Luxor climate is severely arid and it is classified as hyper-desert and extreme Mediterranean type [35]. The rate of annual rainfall in the maximum average is about $0.2 \mathrm{~mm}$. The temperature maximum average ranges between $11^{\circ} \mathrm{C}$ in winter season and $44^{\circ} \mathrm{C}$ in the summer. The wind ranges between $14.2 \mathrm{mph}$ as maximum and $4.5 \mathrm{mph}$. Relative humidity is $56 \%$ in maximum and $17 \%$ in minimum average [36].

After the construction of Aswan High Dam in the 1970, in the whole valley the Nile River has deposited layers of fine-grained alluvial soil that are several meters thick. The result of this is a concentration of salts in the upper soil layers under and near the surface of the temple walls. This played a critical role in contributing to the deterioration of the Pharaonic monuments in Egypt [37] (Figure 6a,b). On the other hand, the monuments in Upper Egypt comprise sensitive sandstones originating from the Gebel el-Silsila region [38].

The groundwater level ascended with values vary between $18 \mathrm{~cm}$ and $1 \mathrm{~m}$, with an average of $30 \mathrm{~cm} /$ year. The depth of the groundwater in Luxor City area varies between 2 and $7 \mathrm{~m}$ from the ground surface. The shallowest depth of the groundwater level is recorded in the El Karnak area, while the deepest level occurs at the desert areas east of the city. During the last four years, the depth to the groundwater level is in a continuous decreasing at $5 \mathrm{~cm} /$ year in Luxor temple area and at $30 \mathrm{~cm} /$ year in the El Karnak temple area [39]. For an average terrain, the depth of the groundwater fluctuated between about $4 \mathrm{~m}$ for well number 4 (beside Nile River) and about $0.80 \mathrm{~m}$ around Ramesseum Temple.

The problems of rock deterioration (spalling and fracturing) are particularly critical in the Theban Necropolis mainly related to humidity and moisture changes of the bedrock [40]. The deterioration of archaeological sites at Luxor is mainly due to the capillary raising of groundwater [41] and tends to decrease the durability of monumental sandstones, as in the case of the reliefs of Hatshepsut (identifiable by the presence of a feminized grammatical form in the accompanying inscription). Moreover, these sandstone blocks, lying directly on the earth, and, therefore, are easily penetrated by groundwater and are in an extremely deteriorated state [42] (Figures 7a,b, 8a,b, 9a,b and 10a,b).

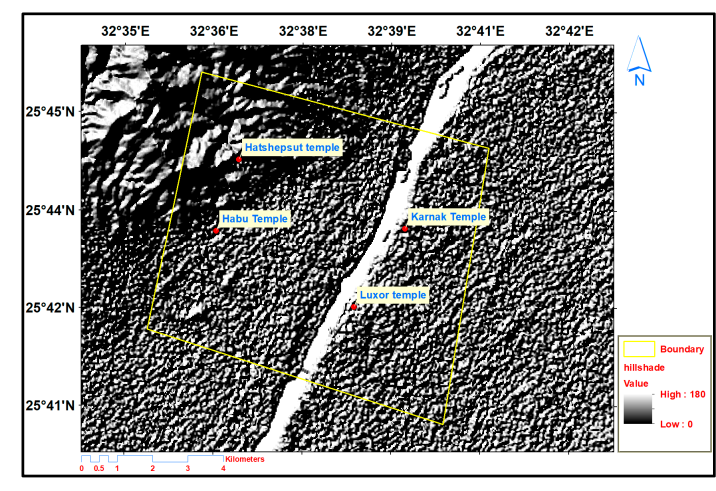

(a)

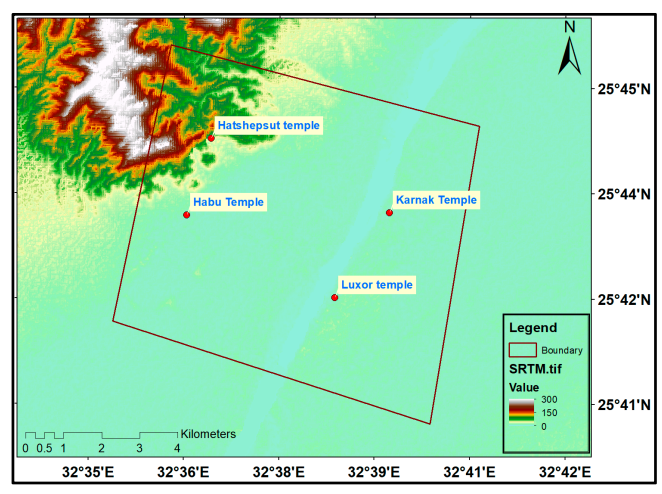

(b)

Figure 6. Hill shade (a) and two-dimensional (2D) (b) showing the topographic and elevation properties around the study area. 


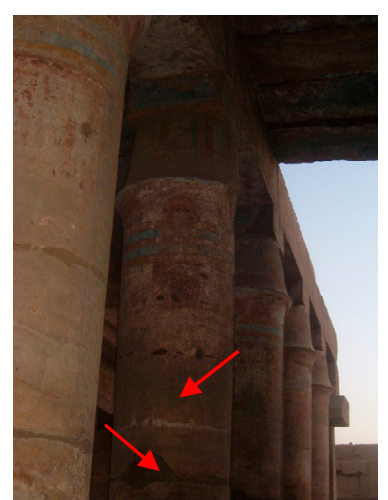

(a)

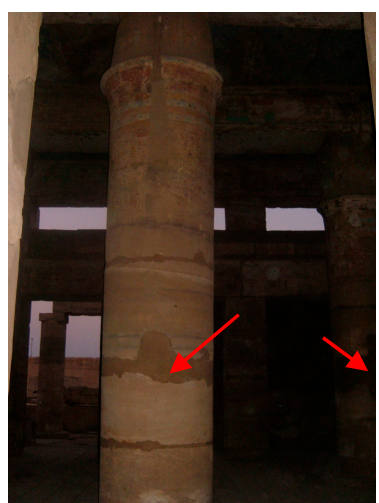

(b)

Figure 7. Deterioration in the walls of El Karnak temple $(\mathbf{a}, \mathbf{b})$.

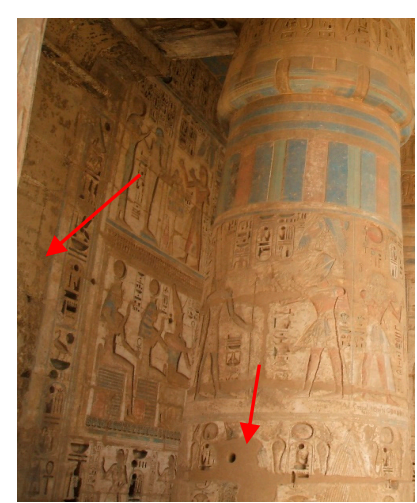

(a)

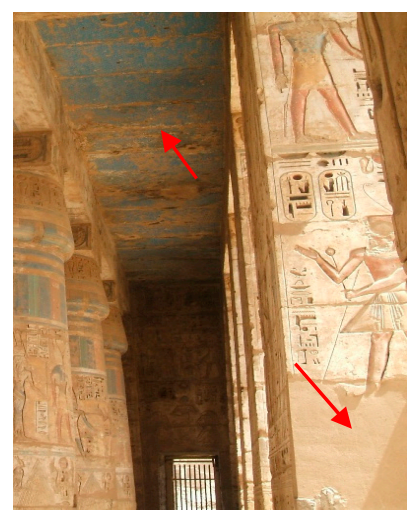

(b)

Figure 8. The walls Deterioration in Medinet Habu temple (a,b).

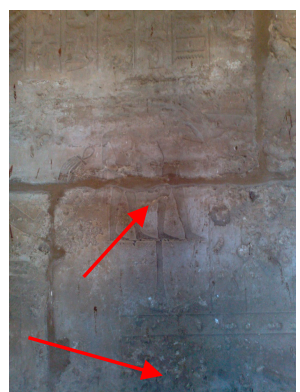

(a)

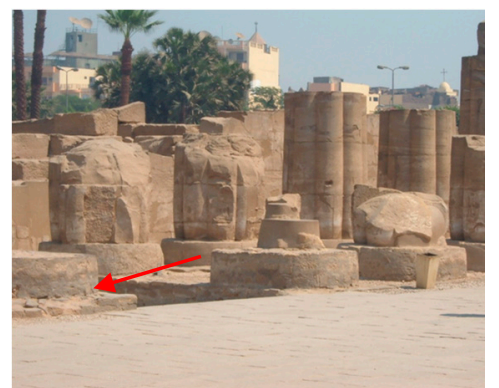

(b)

Figure 9. Deterioration in the walls of Luxor temple $(\mathbf{a}, \mathbf{b})$. 


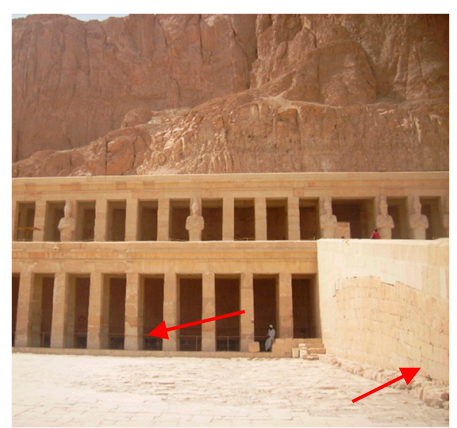

(a)

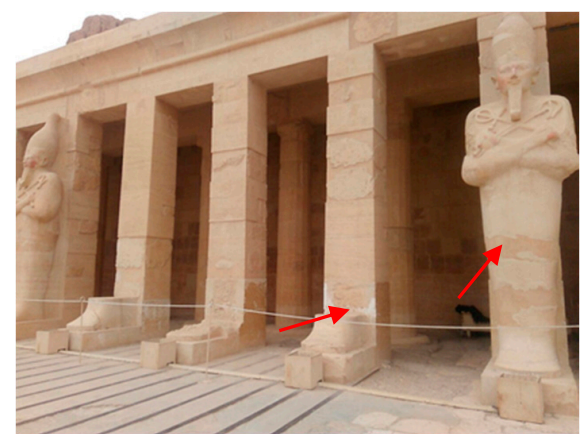

(b)

Figure 10. Deterioration in the inscriptions and writings in the walls of Hatshepsut temple $(\mathbf{a}, \mathbf{b})$.

\section{Materials and Methods}

\subsection{Materials}

The required satellite imagery (Table 1) for the study area were downloaded from the USGS Earth Explorer (SRTM, Landsat TM 1984, Coronaj-3 1964) and from ESA web site Sentinel 2. Finally, the National Authority for Remote Sensing and Space Science (NARSS) provided the high resolution data (Quickbird 2005) and the collection of topographic sheets 1:50,000 from the Survey of Egypt. Hydrogeological and Geological sheet was collected from National authority for remote sensing and space science. The ground truth data were in the form of reference data points collected using randomly points by Quickbird image. Processing the images interpretation is done in ENVI 5.1 software.

Table 1. Main satellite images properties.

\begin{tabular}{cccccc}
\hline Number & Satellite & Sensor & Resolution $(\mathbf{m})$ & Acquisition Date & Source \\
\hline 1 & Corona & KH-4A & $1.8 \mathrm{~m}$ & August 1964 & USGS \\
2 & Landsat & TM & $30 \mathrm{~m}$ & October 1984 & GLCF \\
3 & Quickbird 2 & XS/P & $0.6 \mathrm{~m}$ & November 2005 & NARSS \\
4 & Sentinel & 2A & $10 \mathrm{~m}$ & November 2016 & USGS \\
\hline
\end{tabular}

\subsection{Methods}

\subsubsection{Image Processing}

\section{Band Combination}

Remote sensing data have become one of the important sources of information for studying vegetation, from global continental down to a local scale [43,44]. In particular, spectral vegetation indices are widely used for monitoring, analysing, and mapping temporal and spatial variations in vegetation structure and in biophysical parameters [45]. Vegetation is one of the most important components of the ecosystems [46]. The use of Index-based built-up area is a very simple and rapid method for mapping urban area and sequentially monitoring urban expansion [47]. Moreover, bare-soil plays an important role as an indicator of urban expansion [48]. In this study, the BSI and BRBA indices are used and computed from TM and Sentinel 2 (see Equations (1) to (4)). These indices are related to built-up area and to bare soil, respectively.

In particular, to compute Band Ratio for Built-up Area (BRBA) TM band 3 and 5 and Sentinel 2 band 4 and 12 were used, respectively. These indices are expressed as [49]: 
Assessment of the BSI (bare soil index) showed that the areas covered with mulch has different physicochemical properties of sand dunes with other area [50]. Bare Soil Index (BSI) is a numerical indicator, which is based on blue, red, near infrared, and short wave infrared spectral bands to assess soil variations [51]:

$$
\begin{gathered}
\text { BSI TM }=((S W I R+R e d)-(N I R+B l u e)) /((S W I R+R e d)+(N I R+B l u e))) \text { in Landsat TM4,5 } \\
\text { BSI Sent } 2=((S W I R+R e d)-(N I R+B l u e)) /((S W I R+R e d)+(N I R+B l u e))) \text { in Sentinel } 2
\end{gathered}
$$

Supervised Classification of Images

The supervised classification technique, herein adopted, was based on the maximum likelihood and on training sets (signatures) that were provided by previous field knowledge. Changes are identified by comparing the categorization obtained for each year (Corona 1964, Landsat TM 1984, Quickbird 2005, and Sentinel-2A 2016) that was investigated. Using Corona data is very important for clarifying the changes between 1964 and 2016 (the acquisition date for Corona is 1964), and this data is considered high-resolution $(1.8 \mathrm{~m})$. All of the images are a multi-spectral data, but Corona is one band data. The unsupervised classification has been carried out for Landsat TM 1984, Quickbird 2005, and Sentinel-2A 2016 in ENVI software, but Corona in ArcGIS software. Corona image has been divided into ten classes. Five classes have been chosen by re-classes tool in ArcGIS software. The supervised layers for all of the images have been transformed to digital shapefiles in ArcGIS software to process the measurements. Finally, the changes in the areas have been measured to detect the changes between 1964 and 2016 in the urban layers.

\section{Accuracy Assessment}

In order to assess the accuracy of the obtained change/unchanged areas, the classified change images were compared to their corresponding reference data using the traditional Kappa statistic and overall accuracy. The accuracy assessment has been obtained by randomly separating the dataset into two subsets: training and test. The performance of the classifier has been assessed using an independent balanced (number of samples in different classes very close each other) test set, to avoid that using unbalanced one, the error rate of the classifier would not be representative of its true performance.

In detail, the kappa statistics measures the classification accuracy by accounting for omission and commission error. Kappa statistic is defined (see Equation (5)) [52]:

$$
\mathrm{K}=\text { (observed accuracy }- \text { chance agreement }) /(1 \text { - chance agreement })
$$

The classification accuracy was also estimated from in situ test sites that were selected as the region of interests (350 points; 70 points related to urban area, agricultural area, water bodies area, and desert area) using both the Kappa coefficient and overall accuracy (Table 2).

Results showed that, in the year 1984, the kappa coefficient was 0.73 and the overall accuracy was 78.57 percent. For the next period, 2005, the kappa coefficient decreased to be 0.65 with 72.71 percent of overall accuracy. Finally, the kappa coefficient increased to be 0.945 and the overall accuracy was of 97.94 percent (Figure 11).

Table 2. Kappa Coefficient and overall accuracy of the regions of interest (ROIs)for each period.

\begin{tabular}{ccc}
\hline \multirow{2}{*}{ Year } & \multicolumn{2}{c}{ Luxor Area } \\
\cline { 2 - 3 } & Kappa Coefficient & Overall Accuracy \\
\hline 1984 & $78.5714 \%$ & 0.7306 \\
2005 & $72.7135 \%$ & 0.6501 \\
2016 & $97.9401 \%$ & 0.9450 \\
\hline
\end{tabular}




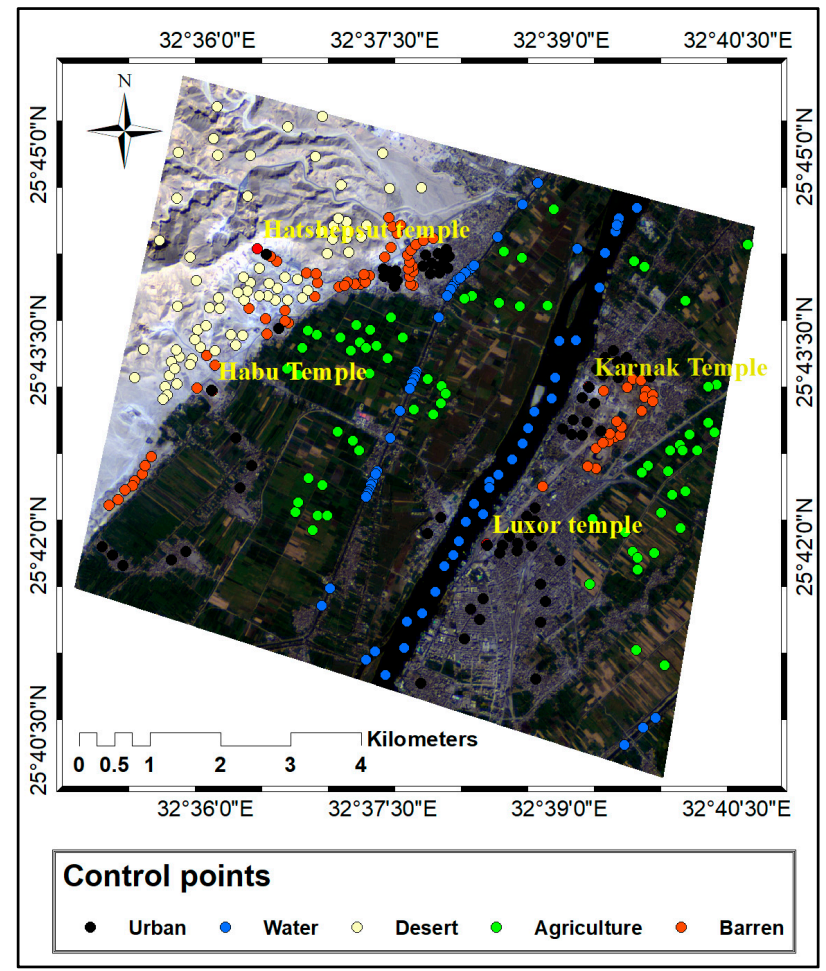

Figure 11. Control points used for Sentinel-2A (20 February 2017) RGB 4,3,2.

\section{Results and Discussion}

The analysis of Corona (1964), Landsat TM (1984), Quickbird (2005), and Sentinel 2 (2016) imageries acquired for the Luxor area revealed that urban areas increased about $7.792 \mathrm{~km}^{2}$ from 1964 to 1984, and about $2.734 \mathrm{~km}^{2}$ from 1984 to 2005, and finally about $1.763 \mathrm{~km}^{2}$ from 2005 to 2016 (Table 3) (Figures 12 and 13). In this study, the urban changes from satellite images taken forms the same study area at different acquisition dates. In particular, the analysis of Corona image, Landsat TM, Quickbird, and Sentinel-2A in Luxor revealed that urban land increased about $63.4 \%$ from 1964 to 1984 , about $22.31 \%$ from 1984 to 2005 , and about $14.34 \%$ from 2005 to 2016 . These mean that the increase in urban area has the same way between 1964 and 2016 at Luxor area. It is very clear that the increase in Luxor area between 1964 and 1984 has very high percentage $63.4 \%$. On the other hand, the annual average of the increase in the urban layer presented about $236.32 \mathrm{~m}^{2}$. Our background about the study area expose that this increase is related to the tourism activities around the archaeological area. Also, it is observed that the encroachment in the urban land at Luxor was in the boundary near to the desert, especially on the West bank of Nile River. The main reasons about the environmental problems in the temples area are related to the unplanned encroachment, bad sewage networks, and Agricultural drainages.

Table 3. Total changes in the urban and agriculture areas (expressed in $\mathrm{km}^{2}$ ) in Luxor area.

\begin{tabular}{lcccccccc}
\hline Class & $\begin{array}{c}\text { Study } \\
\text { Area }\end{array}$ & $\begin{array}{c}\mathbf{1 9 6 4} \\
\mathbf{( \mathbf { k m } ^ { 2 } )}\end{array}$ & $\begin{array}{c}\text { Change } \\
\text { Detection } \\
\pm \mathbf{k m}^{\mathbf{2}}\end{array}$ & $\begin{array}{c}\mathbf{1 9 8 4} \\
\mathbf{( \mathbf { k m } ^ { \mathbf { 2 } } )}\end{array}$ & $\begin{array}{c}\text { Change } \\
\text { Detection } \\
\pm \mathbf{k m}^{\mathbf{2}}\end{array}$ & $\begin{array}{c}\mathbf{2 0 0 5} \\
\left.\mathbf{( k m}^{\mathbf{2}}\right)\end{array}$ & $\begin{array}{c}\text { Change } \\
\text { Detection } \\
\pm \mathbf{k m}^{\mathbf{2}}\end{array}$ & $\begin{array}{c}\mathbf{2 0 1 6} \\
\left.\mathbf{( k m}^{\mathbf{2}}\right)\end{array}$ \\
\hline Urban Luxor & 4.539 & 7.792 & 12.331 & 2.734 & 15.065 & 1.763 & 16.828 \\
\hline
\end{tabular}




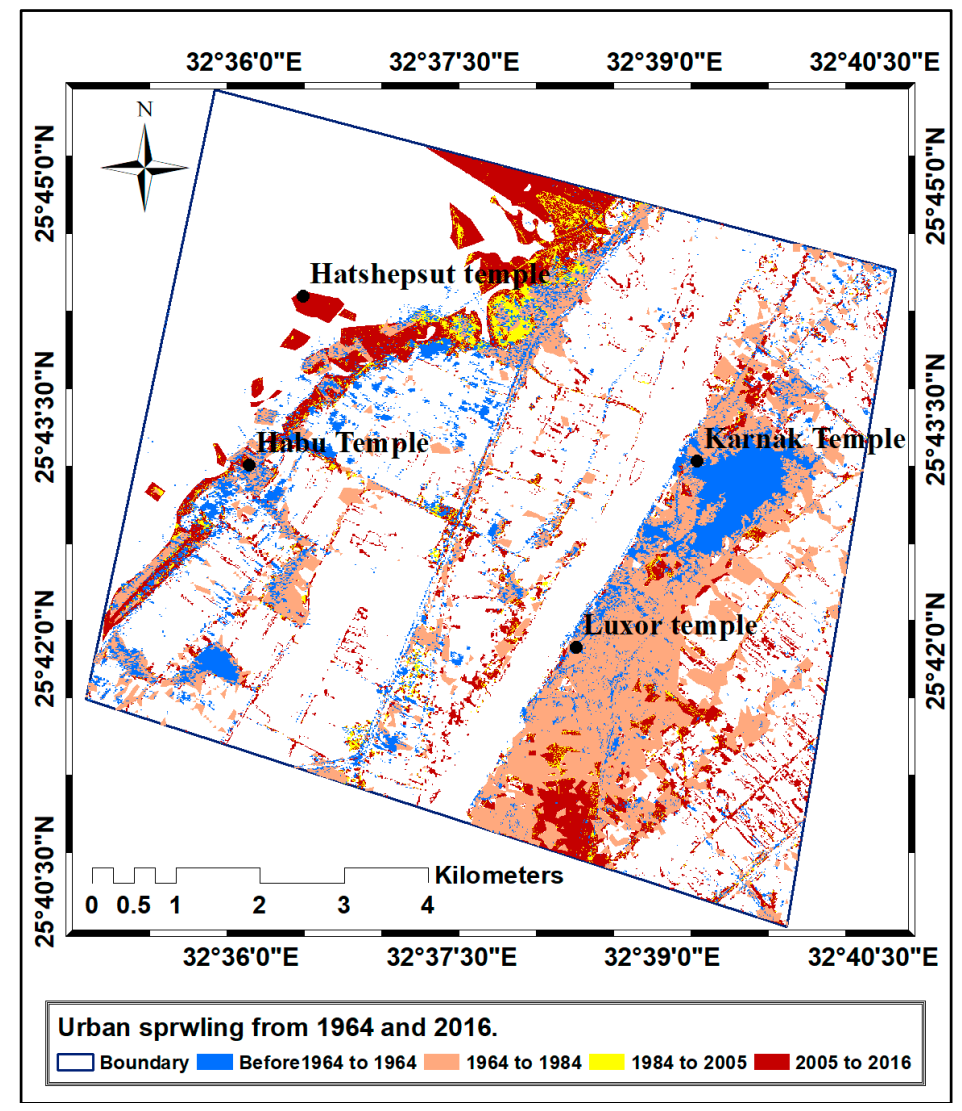

Figure 12. Changes in the urban area between 1964 and 2016.

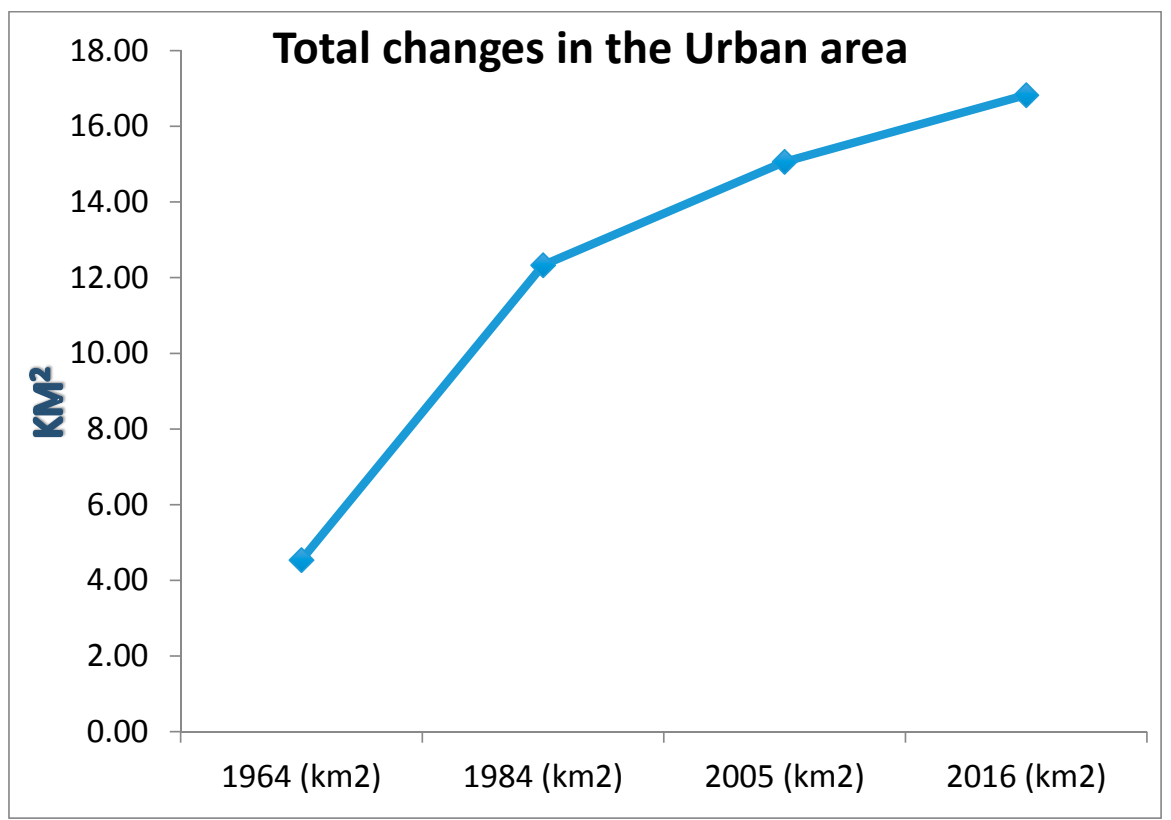

Figure 13. Total changes in the urban area by the graph.

The accuracy assessment has been built by comparison between standard (Urban, agriculture, desert, water, and barren area) points, which have been chosen in Sentinel-2A image (high resolution $10 \mathrm{~m}$ ) and the output in classifications in ENVI 5.1 (post classification, confusion matrix, and using ground truth (ROIs). This method has been used to measure the classification truth in the classified 
images by overall accuracy (Dividing the total number of correct pixels (diagonal) by the total number of pixels in the error matrix) and Kappa Coefficient (measure of agreement between the classification map and the reference data).

Band combination techniques were used to identify the changes in the vegetation and built up indices between 1984 and 2016. The assessment included two indices BRBA (Band Rotation for Built up Area), and BSI (bare soil index). The result of this study, based on the classification of the BRBA indices, showed that in Luxor there is a continuous increasing of urban areas. This can be seen in the 2016 from the classified image. In particular, urban areas and roads have been constructed after 1984 on the eastern, centre, as well as on the western sides of the area (Figure 14), and in the southwest direction. Moreover, BSI indices showed the extension of agriculture area within the study area in the northwest direction. Built-up was generally very clear through in the vegetation from the BSI layout out in the 2016 date (Figure 15).

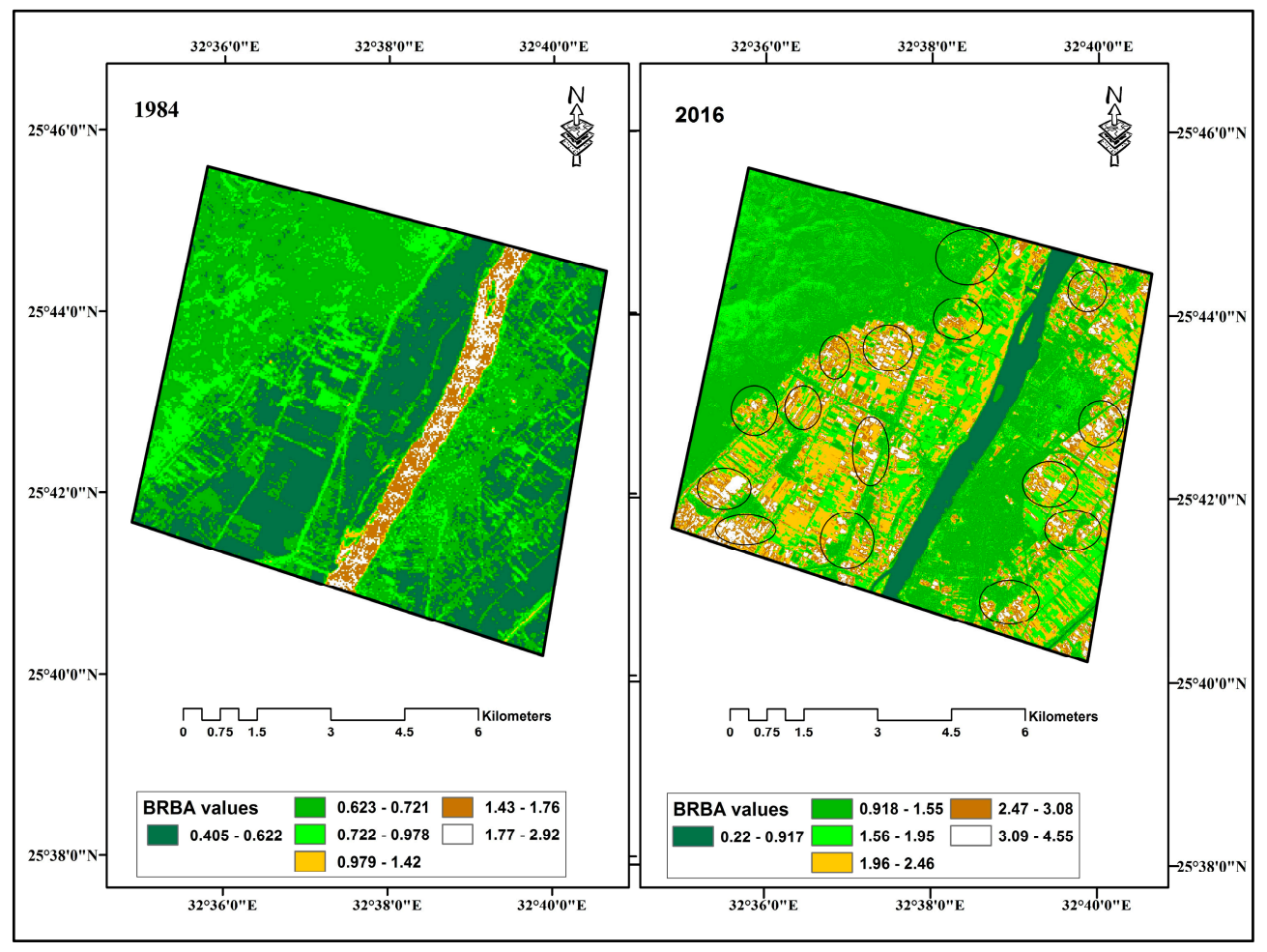

Figure 14. The changes in Band Rotation for Built up Area (BRBA) indices in the area between 1984 and 2016.

Many environmental studies have been carried out in the Luxor area [53-63]. Most of these references focused on hydrology, geology, and climate setting for monitoring the environmental status around the archaeological areas, which are necessary, but performed using the classical methods.

Today, satellite images as Sentinel 2 are systematically available free of charge for large coverage, and can be used for accurate mapping as well as for documenting and analyzing the historical and contemporary human activities around cultural heritage sites [64].

Luxor is an obligatory place for the tourist to Egypt for its incredible wealth of antiquities, the natural beauty, and the Nile River. Antiquities and monuments date back to early pharaonic dynasties (3000 B.C.), in addition to later Roman, Coptic, and Islamic periods. Among others, Luxor's main landmarks include 'world heritage' sites, such as the royal tombs of the Kings' Valley, Queens' Valley, and the Tombs of the Nobles. It also includes masterpieces, such as the Colossi of Memnon, Karnak Temple (the most imposing Pharaonic temple in all of Egypt), and Luxor temple. They represent some of the finest examples of mankind's early civilization and rank among its greatest cultural 
achievements. It has therefore always fascinated travelers from all over the world. Tourism in Luxor has been a major economic activity of most of its population, as it is the source of various jobs and business opportunities. The local economy is therefore largely depended on tourism. Besides the importance of Luxor city as a tourism spot and the increasing in the population numbers in Luxor city, most of the urban encroachment has been focused on the archaeological areas.

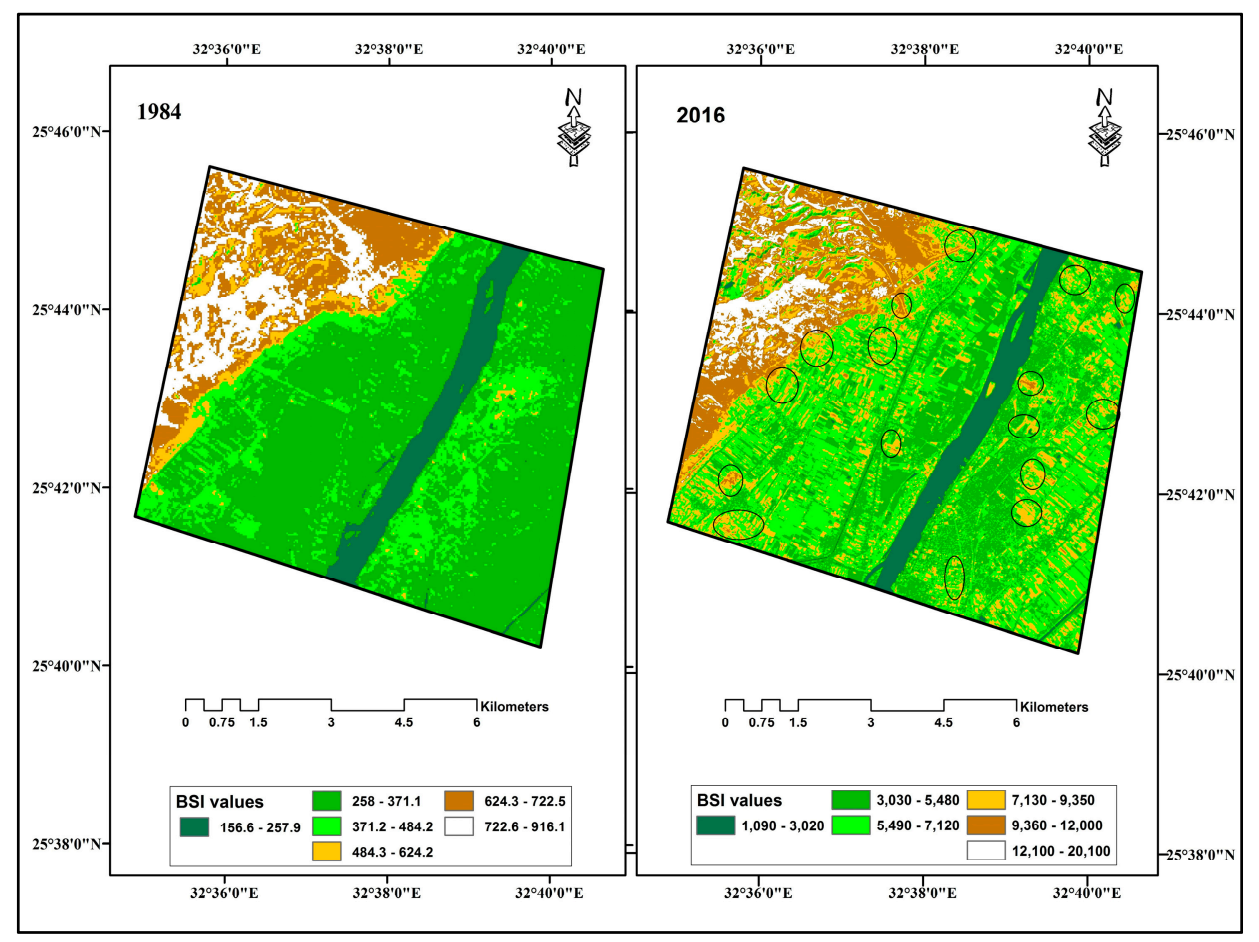

Figure 15. The changes in bare soil index (BSI) indices in the area between 1984 and 2016.

Unplanned wastewater and drinking-water networks are inevitable results of the randomly urban crawling around the monuments temples. In this paper, we propose the use of historical archives along with recent satellite acquisitions, in order to recover the past information and set up a systematic monitoring of ongoing changes using current satellite acquisitions. The analysis is focused around the four temples of Luxor city (Egypt). Results of this study have been developed taking advantages of GIS and RS based on the utilization of a variety of environmental factors.

In particular, the analysis of Corona 1964, Landsat TM 1984, Quickbird 2005, and Sentinel 22016 in Luxor city revealed that urban areas increased about 63.4\% from 1964 and 1984, about $22.3 \%$ from 1984 to 2005, and finally about $14.3 \%$ from 2005 to 2016. It is observed that the highest level in the urban increasing was between 1964 and 1984; this curve went down from 1984 to 2005, and more again from 2005 to 2016.

\section{Recommendation}

The information on the ongoing changes in the investigated area obtained from the multitemporal analysis can fruitfully support the smart management of the archaeological areas, in particular providing insights for the definition of zonations, as usually required by UNESCO for the preservation of heritage. The following recommendations highlight the operational role that the remote sensing may have to fruitfully support management and decision process. According to the periodic 2017 UNESCO reports (see for example (http:/ / whc.unesco.org/en/soc/3597 and http:/ / whc.unesco.org/ en/soc/751) on the status of this archaeological area, the main factors affecting the archaeological property are the following: 
- Deliberate destruction of heritage

- Flooding

- Housing

- Impacts of tourism/visitor/recreation

- Land conversion

- Management activities

- Management systems/management plan

- Water (rain/water table)

- Other Threats

The UNESCO reports of the previous years reported among the others the following factors, which considered to adversely affect the property:

- $\quad$ Rising underground water level

- Risks of flooding (Valleys of Kings and Queens)

- Absence of a comprehensive Management Plan

- Major infrastructure and development projects taking place or scheduled

- Uncontrolled urban development

- Housing and agricultural encroachment on the West Bank of the Nile

Following the suggestions of the Strategy for Risk Reduction at World Heritage Properties, which were presented and approved by the World Heritage Committee during its 31st session in 2007, priority actions have to be structured around the needs to strengthen the protection of World Heritage, and, at the same time, contribute to its sustainable development. When considering this approach, on the basis of the results obtained from the satellite investigations and the ancillary information, we propose the following recommendations:

(I). Current space technologies could be incorporated in traditional technologies for improving environmental analysis, following Lasaponara et al. [65-69] and the approaches proposed by UNESCO in the Man and Biosphere Program (MAB); that is based on the application of the concept of "biosphere reserves

(II). In Luxor, the risk mitigation can be performed using a "Zonation System" that applies different management policies to different zones $\{50 \mathrm{~m}\}$. The archaeological area is to be surrounded by three areas, as suggested by UNESCO. The first area for monitoring; the second for the research, experiment, education, and training; and, the third area for tourism and recreation (Figure 16). The proposed zonation is based on the consideration that for the Hatshepsut temple the areas identified have to cope with the need to.

(III). As a result of the bad environmental status around the archaeological area of Luxor, it becomes very necessary to choose some suitable places to dig some trenches in order to collect the ground water, including the wastewater originated by the urban uncontrolled expansion (to cope with the needs highlighted in the UNESCO reports). Figure 17 shows the location of the trenches that are connected with pumps defined considering ancillary information and the slope of the area, also depicted in Figure 17. When considering the slope and topographical features of the area, these trenches, connected with pumps, should be located at a depth around $9 \mathrm{~m}$. Moreover, these wastewaters will be transferred to a water recycling station, which finally will move them to the nearest canal, to purify water made them suitable for irrigation.

(IV). In the next future, additional investigations based on GIS-modeling methodology will also be addressed to the identification the alternative sites for urban areas and agricultural activities to minimize their adverse impact on the cultural properties. Potential feasible sites will be identified on the basis of external impact factors such as Roads, DEM, archaeological area, Agriculture land, and Urban (see Figures 17 and 18), management purposes, following the UNESCO recommendations. 


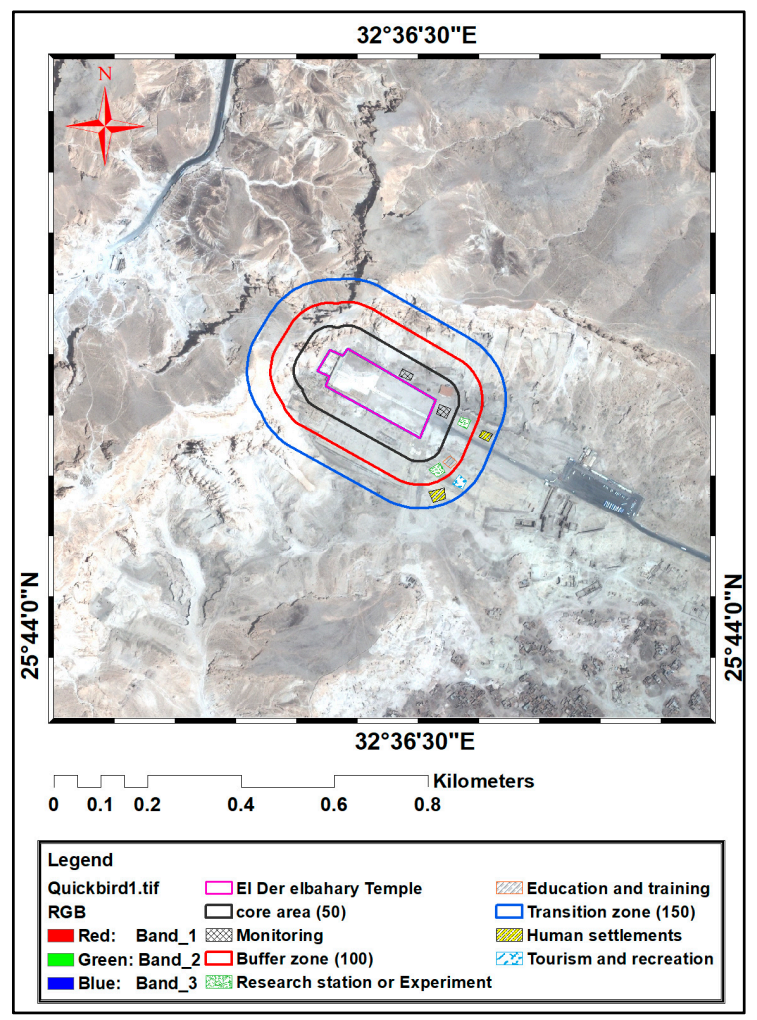

Figure 16. Proposed zonation areas around Hatshepsut temple by Quick bird satellite image 2005 (RGB).

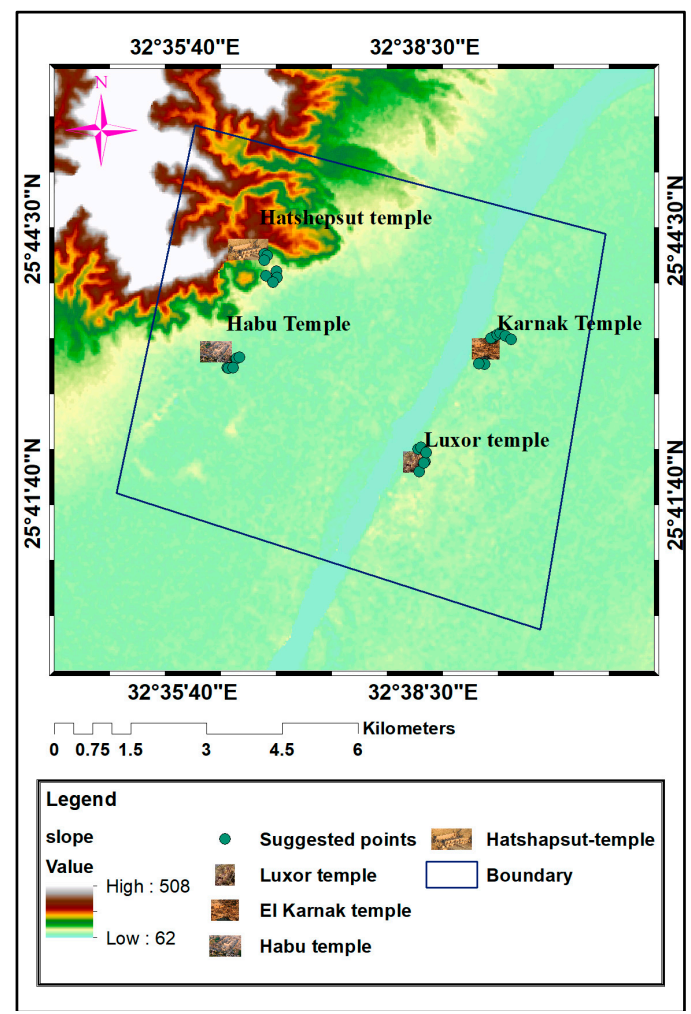

Figure 17. Proposed Points for the recommended trenches around the temples. 


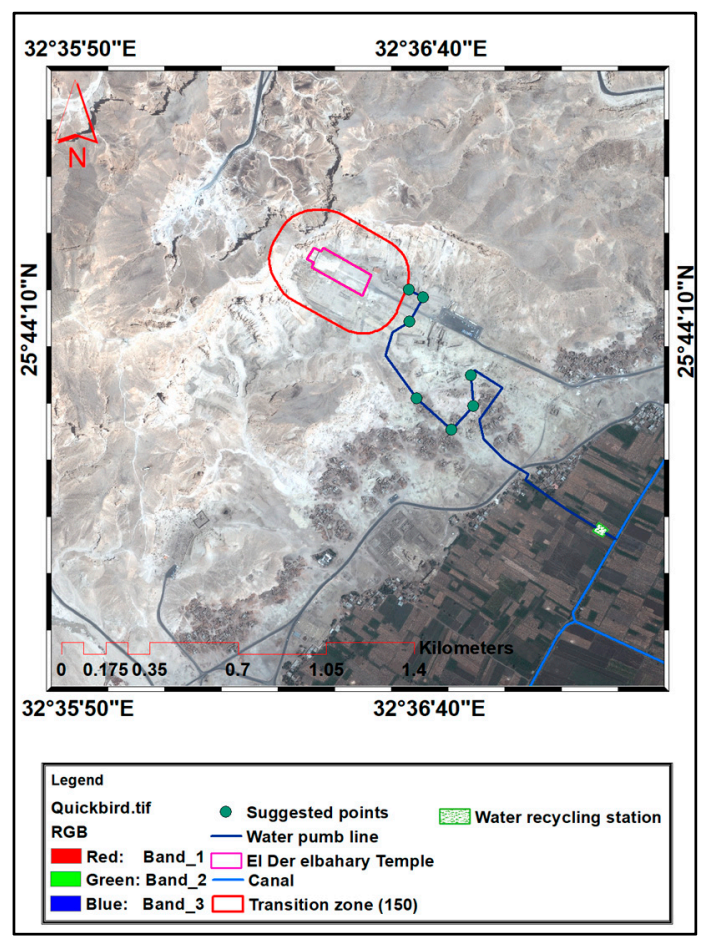

Figure 18. Proposed GIS-modeling around Hatshepsut temple by Quick bird satellite image 2005 (RGB).

\section{Conclusions}

Recent improvements in earth observation technologies offer advanced technical characteristics that enable new applications specifically for the documentation, enhancement, risk monitoring, and preservation of cultural heritage. In particular, the most recent space missions as the ESA sentinel are specifically concerned with risk estimation and management, systematically acquired for the entire globe.

This study presents the possibility of using these modern technological tools in terms of design and planning a smart and sustainable use of cultural heritage resources. The aims of our investigations were focused on the estimation of the effect of urban crawling around some Temples of Luxor city, which is considerably affected by continuous changes. The survey study has shown that most of the environmental problems around the archaeological areas have been coming from the high level of the groundwater depth and the essential reason is the unplanned urban encroachment. Results from our analysis conducted using data acquired in 1964, 1984, 2005, and 2016 showed the spatial dimension of the changes in urban and agricultural areas that appeared clearly in the images of classification and extracted indices. On the basis of the analysis, we carried out mitigation actions that were also identified and suggested. A "Zonation System" has been proposed and mapped in order to support the preservation strategies that can take benefits from different management policies devised for the different identified zones.

Sustainable management and exploitation as well as conservation and mitigation strategies are mandatory to reduce decay phenomena, threats and human actions that may accelerate decay dynamics or produce significant deterioration and/or alteration of cultural heritage and "its environment". In this context, remote sensing technologies can offer useful data to timely update information and documentation, as well as reliable tools for the systematic monitoring of cultural properties. The tremendous availability of advanced remote sensing data has opened today new challenges and prospective information that were unthinkable several years ago. In particular, for archaeological sites and landscape remote sensing can provide useful data not only for probing the subsurface to unveil 
sites and artefacts, but also for the management, valorisation, and preservation, for detecting changes as well as for assessing degradation and emerging threats.

Acknowledgments: This article is a part of the Ph.D. thesis of Abdelaziz Elfadaly, so the authors would like to thank the Italian National Research Council (CNR) at Tito Scalo, Potenza for supporting the research activities. Special thanks giving to National Authority for Remote sensing and Space science (NARSS) for funding the satellite data. Also, many thanks to the University of Basilicata for supporting the Ph.D. activities of Abdelziz Elfadaly.

Author Contributions: The research article included three main contributions; archeology, hydrogeology, and remote sensing techniques. Osama Wafa, Mohamed Abouarab, and Pier Spanu provided the monuments descriptions. The change detection and remote sensing indices techniques have been analyzed by Rosa Lasponara and Abdelaziz Elfadaly. The environmental problems has been analyzed by Antonella Guida. The last version of the article has been revised by Rosa Lasaponara, Pier Spanu, and Antonella Guida.

Conflicts of Interest: The authors would like to hereby certify that no conflict of interest in the collection, analyses, and the interpretation of data; in the writing of the manuscript, and in the decision to publish the results. Authors would like also to declare that the funding of the study has been supported by the authors institutions.

\section{References}

1. Lasaponara, R.; Masini, N. Satellite remote sensing in archaeology: Past, present and future perspectives. J. Archaeol. Sci. 2011, 38, 1995-2002. [CrossRef]

2. Lasaponara, R.; Masini, N. Satellite synthetic aperture radar in archaeology and cultural landscape: An overview. Archaeol. Prospect. 2013, 20, 71-78. [CrossRef]

3. Chen, F.; Lasaponara, R.; Masini, N. An overview of satellite synthetic aperture radar remote sensing in archaeology: From site detection to monitoring. J. Cult. Herit. 2017, 23, 5-11. [CrossRef]

4. Cigna, F.; Lasaponara, R.; Masini, N.; Milillo, P.; Tapete, D. Persistent scatterer interferometry processing of COSMO-SkyMed StripMap HIMAGE time series to depict deformation of the historic centre of Rome, Italy. Remote Sens. 2014, 6, 12593-12618. [CrossRef]

5. Lasaponara, R.; Leucci, G.; Masini, N.; Persico, R.; Scardozzi, G. Towards an operative use of remote sensing for exploring the past using satellite data: The case study of Hierapolis (Turkey). Remote Sens. Environ. 2016, 174, 148-164. [CrossRef]

6. Beck, A.; Philip, G.; Abdulkarim, M.; Donoghue, D. Evaluation of Corona and Ikonos high resolution satellite imagery for archaeological prospection in Western Syria. Antiquity 2007, 81, 161-175. [CrossRef]

7. Wilkinson, K.; Philip, G.; Beck, A. Satellite imagery as a resource in the prospection for archaeological sites in central Syria. Geoarchaeology 2006, 21, 735-750. [CrossRef]

8. Parcak, S. Satellite Remote Sensing Methods for Monitoring Archaeological Tells in the Middle East. J. Field Archaeol. 2007, 32, 65-81. [CrossRef]

9. Etaya, M.; Sudo, N.; Sakata, T. Detection of subsurface ancient Egyptian remains utilizing optical and microwave satellite data. In Proceedings of the 2000 IEEE International Geoscience and Remote Sensing Symposium, Honolulu, HI, USA, 24-28 July 2000; Volume 6, pp. 2480-2482.

10. Robinson, C.A. Potential and applications of radar images in Egypt. Egypt. J. Remote Sens. Space Sci. 1998, 1, 25-56.

11. Parcak, S. Site survey in Egyptology. In Egyptology Today; Wilkinson, R.H., Ed.; Cambridge University Press: Cambridge, UK, 2008; pp. 57-76.

12. Stewart, Ch.; Lasaponara, R.; Schiavon, G. ALOS PALSAR Analysis of the Archaeological Site of Pelusium. Archaeol. Prospect. 2013, 2, 109-116. [CrossRef]

13. Unesco Report. Available online: http:/ / whc.unesco.org/en/soc/3597 (accessed on 15 November 2017).

14. Unesco Report. Available online: http://whc.unesco.org/en/soc/751 (accessed on 15 November 2017).

15. Masini, N.; Capozzoli, L.; Chen, P.; Chen, F.; Romano, G.; Lu, P.; Tang, P.; Sileo, M.; Ge, Q.; Lasaponara, R. Towards an operational use of geophysics for archaeology in Henan (China): Methodological approach and results in Kaifeng. Remote Sens. 2017, 9, 809. [CrossRef]

16. Themistocleous, K.; Ioannides, M.; Agapiou, A.; Hadjimitsis, D.G. The methodology of documenting cultural heritage sites using photogrammetry, UAV, and 3D printing techniques: The case study of Asinou Church in Cyprus. Proc. SPIE 2015, 953510. [CrossRef] 
17. Tapete, D.; Cigna, F.; Donoghue, D.N.M. Looting marks in space-borne SAR imagery: Measuring rates of archaeological looting in Apamea (Syria) with TerraSAR-X Staring Spotlight. Remote Sens. Environ. 2016, 178, 42-58. [CrossRef]

18. Tapete, D.; Cigna, F. InSAR data for geohazard assessment in UNESCO World Heritage sites: State-of-the-art and perspectives in the Copernicus era. Int. J. Appl. Earth Obs. Geoinf. 2017, 63, 24-32. [CrossRef]

19. Agapiou, A.; Lysandrou, V.; Hadjimitsis, D. Optical Remote Sensing Potentials for Looting Detection. Geosciences 2017, 7, 98. [CrossRef]

20. Convention Concerning the Protection of the World Cultural and Natural Heritage. Available online: http:/ / whc.unesco.org/en/conventiontext/ (accessed on 15 November 2017).

21. List of World Heritage in Danger. Available online: http://whc.unesco.org/en/danger/ (accessed on 15 November 2017).

22. Weeks, K.R.; Hetherington, N.J. The Valley of the Kings, Luxor, Egypt: Site Management Master Plan; Theban Mapping Project: Cairo, Egypt, 2006; p. 27.

23. Lloyd, A.B. A Companion to Ancient Egypt; John Wiley \& Sons: Hoboken, NJ, USA, 2010; Volume 1, p. 442.

24. Wilkinson, R.H. The Complete Temples of Ancient Egypt, 1st ed.; Thames \& Hudson: London, UK, $2000 ;$ p. 47.

25. Murray, M.A. Egyptian Temples; Sampson Low Marston \& Company: London, UK, 2005; pp. 65-105.

26. Bell, C. A Timeless Culture: Egyptian Architecture \& Decorative Arts. Available online: http:/ /bellcr.com/ wp-content/uploads/2006/01/Egyptian-Architecture.pdf (accessed on 21 November 2017).

27. Cust, L.H. Luxor and Its Temples; Billing and Sons, Ltd.: Guildford, UK; Eshek, UK, 1923; pp. 58-59.

28. Harbison, R. Travels in the History of Architecture; MPG Books Ltd.: Bodmin, Cornwall, UK, 2009; pp. $26-27$.

29. Bell, L. Luxor Temple and the Cult of the Royal Ka. J. Near East. Stud. 1985, 44, 251-294. [CrossRef]

30. Nelson, H.H.; Holscher, U. Buried History, Publications of the Oriental Institute of the University of Chicago. Available online: https:/ / oi.uchicago.edu/sites/oi.uchicago.edu/files/uploads/shared/docs/ar/28-59/ 1934_BuriedHistory.pdf (accessed on 22 November 2017).

31. Nelson, H.H. The Egyptian Temple: The Theban temples of the empire period. (Boston, United States). In The Biblical Archaeologist; American Schools of Oriental Research: Boston, MA, USA, 1944; Volume 7, pp. 44-53.

32. Lesko, B.S. Royal Mortuary Suites of the Egyptian New Kingdom. Am. J. Archaeol. 1969, 73, 453-458. [CrossRef]

33. Holden, L. The virtual Egyptian temple. In EdMedia: World Conference on Educational Media and Technology; Association for the Advancement of Computing in Education (AACE): Waynesville, NC, USA, 2006; pp. 3-4.

34. Szafrański, Z.E. Temple of Hatshepsut at Deir El-Bahari, SEASON 2006/2007. Pol. Archaeol. Mediterr. 2007, 19, 250-268.

35. Cuezva, S.; Garcia-Guinea, J.; Fernandez-Cortes, A.; Benavente, D.; Ivars, J.; Galan, J.M.; Sanchez, M. Composition, uses, provenance and stability of rocks and ancient mortars in a Theban Tomb in Luxor (Egypt). Mater. Struct. 2016, 49, 941-960. [CrossRef]

36. Luxor Current Weather Report. Available online: https://www.worldweatheronline.com/luxor-weather/ qina/eg.aspx (accessed on 15 November 2017).

37. Campos, E. A groundwater flow model for water related damages on historic monuments-Case study West Luxor Egypt. Vatten 2009, 65, 247-254.

38. Fitzner, B.; Heinrichs, K.; La Bouchardiere, D. Weathering damage on Pharaonic sandstone monuments in Luxor-Egypt. Build. Environ. 2003, 38, 1089-1103. [CrossRef]

39. Selim, S.A.; Khedr, E.S.; Falasteen, A.W.; Kamel, E.R. Reasons of local rise in groundwater level at Luxor city area, upper Physical Setting Climate Geomorphology. In Proceedings of the 5th International Conference on the Geology of the Arab World, Giza, Egypt, 21-24 February 2000; pp. 901-910.

40. Mclane, J.; Wust, R. Flood Hazards and Protection Measures in the Valley of the Kings. Cult. Resour. Manag. 2000, 23, 35-38.

41. Ahmed, A.A.; Fogg, G.E. The impact of groundwater and agricultural expansion on the archaeological sites at Luxor, Egypt. J. Afr. Earth Sci. 2014, 95, 93-104. [CrossRef]

42. Roehrig, C.H.; Dreyfus, R.; Keller, C.A. Hatshepsut from Queen to Pharaoh; The Metropolitan Museum of Art: New York, NY, USA, 2006; pp. 181-182.

43. Moreira, E.P.; Valeriano, M.d.M.; Sanches, I.D.A.; Formaggio, A.R. Topographic Effect on Spectral Vegetation Indices From Landsat Tm Data: Is Topographic Correction Necessary? Bol. Ciências Geodésicas 2016, 22, 95-107. [CrossRef] 
44. Gitelson, A.A.; Kaufman, Y.J.; Stark, R.; Rundquist, D. Novel algorithms for remote estimation of vegetation fraction. Remote Sens. Environ. 2002, 80, 76-87. [CrossRef]

45. Chandra, P. Performance evaluation of vegetation indices using remotely sensed data. Int. J. Geomat. Geosci. 2011, 2, 231-240.

46. Fu, A. Urban Growth and LULC Change Dynamics Using Landsat. Available online: https://uwspace. uwaterloo.ca/bitstream/handle/10012/8271/Fu_Anqi.pdf;sequence=3 (accessed on 22 November 2017).

47. Li, S.; Chen, X. A new bare-soil index for rapid mapping developing areas using landsat 8 data. Int. Arch. Photogramm. Remote Sens. Spatial Inf. Sci. 2014, 40, 139-144. [CrossRef]

48. Waqar, M.M.; Mirza, J.F.; Mumtaz, R.; Hussain, E. Development of New Indices for Extraction of Built-Up Area \& Bare Soil. Open Access Sci. Rep. 2012, 1, 1-4.

49. Hashemimanesh, M.M.; Matinfar, H.R.; Alavipanah, S.K.; Zehtabian, G. Landsat thermal band efficiency on characterizing mulched soil surface. Int. Agrophys. J. 2012, 26, 249-257. [CrossRef]

50. Konda, A.; Hongo, D.; Ichikawa, H.; Koji Kajiwara, H.Y.; Honda, Y. The Study on Vegetation Structure Index using BRF Property with Satellite Sensors. Image 2002, 12, 8-11.

51. Senseman, G.M.; Bagley, C.F.; Tweddale, S.A. Accuracy Assessment of the Discrete Classification of Remotely-Sensed Digital Data for Land cover Mapping. Available online: http:/ /www.dtic.mil/docs/ citations / ADA296212 (accessed on 21 November 2017).

52. Ahmed, A.A.; Fogg, G.E.; Gameh, M.A. Water use at Luxor, Egypt: Consumption analysis and future demand forecasting. Environ. Earth Sci. 2014, 72, 1041-1053. [CrossRef]

53. US Agency for International Development (USAID). Scoping Statement For CITY OF LUXOR Groundwater Lowering of Antiquities Sites on the West Bank; National Organization for Potable Water and Sanitary Drainage (NOPWASD): Cairo, Egypt, 2007; pp. 1-64.

54. AbouelFadl, S.; El-lithy, K. Impact Assessment of Global Warming on Egypt. 2014, pp. 352-360. Available online: https:/ /www.academia.edu/10487070/Impact_Assessment_of_Global_warming_on_ Egypt (accessed on 15 November 2017).

55. Tully, G.; Hanna, M. One Landscape, Many Tenants: Uncovering Multiple Claims, Visions and Meanings on the Theban Necropolis. Archaeologies 2013, 9, 362-397. [CrossRef]

56. Graham, A.; Kristian, S.; Morag, D.H.; Sarah, J.; Aurélia, M.; Marie, M.; Benjamin, P. Reconstructing Landscapes and Waterscapes in Thebes, Egypt. eTopoi J. Anc. Stud. 2012, 3, 135-142.

57. Graham, A.; Strutt, K.D.; Hunter, M.A.; Pennington, B.T.; Toonen, W.H.J.; Barker, D.S. Theban Harbours and waterscapes survey. J. Egypt. Archaeol. 2014, 100, 35-47.

58. El-Asmar, H.M.; Ahmed, M.H.; Taha, M.M.N.; Assal, E.M. Human Impacts on Geological and Cultural Heritage in the Coastal Zone West of Alexandria to Al-Alamein, Egypt. Geoheritage 2012, 4, 263-274. [CrossRef]

59. Elwaseif, M.; Ismail, A.; Abdalla, M.; Abdel-Rahman, M.; Hafez, M.A. Geophysical and hydrological investigations at the west bank of Nile River (Luxor, Egypt). Environ. Earth Sci. 2012, 67, 911-921. [CrossRef]

60. Kobashi, T. Greenland Temperature, Climate Change, and Human Society during the Last 11,600 years. Ph.D. Thesis, University of California, San Diego, CA, USA, 2007.

61. Agrawala, S.; Moehner, A.; El Raey, M.; Conway, D.; Aalst, M.V.; Hagenstad, M.; Smith, J. Development and Climate Change in Egypt: Focus on Coastal Resources and the Nile; Organisation for Economic Co-operation and Development: Paris, France, 2004; pp. 1-68.

62. Hassan, K.E. Impacts of Future Climate Change on Egyptian Population, International Union for the Scientific Study of Population (IUSSP). In Proceedings of the XXVII IUSSP International Population Conference, Busan, Korea, 31 August 2013; pp. 1-15.

63. Clarke, J.; Brooks, N.; Banning, E.B.; Bar-Matthews, M.; Campbell, S.; Clare, L.; Cremaschi, M.; di Lernia, S.; Drake, N.; Gallinaro, M.; et al. Climatic changes and social transformations in the Near East and North Africa during the 'long' 4th millennium BC: A comparative study of environmental and archaeological evidence. Quat. Sci. Rev. 2015, 136, 96-121. [CrossRef]

64. Stubbs, J.H.; McKee, K.L.R. Applications of Remote Sensing to the Understanding and Management of Cultural Heritage Sites. In Remote Sensing in Archaeology; Interdisciplinary Contributions to Archaeology; Springer: New York, NY, USA, 2007; pp. 515-540. 
65. Lasaponara, R.; Elfadaly, A.; Attia, W. Using remote sensing and GIS techniques for monitoring the environmental status the problems and the solutions around Esna temple at luxor, Egypt. In Proceedings of the International Conference of Advanced in Remote Sensing for Cultural Heritage, Frascati, Italy, 12-13 November 2015.

66. Lasaponara, R.; Elfadaly, A.; Attia, W. Low Cost Space Technologies for Operational Change Detection Monitoring Around the Archaeological Area of Esna-Egypt. In Proceedings of the International Conference on Computational Science and Its Applications, Beijing, China, 4-7 July 2016; Springer: Beijing, China, 2016; pp. 611-621.

67. Lasaponara, R.; Murgante, B.; Elfadaly, A.; Qelichi, M.M.; Shahraki, S.Z.; Wafa, O.; Attia, W. Spatial Open Data for Monitoring Risks and Preserving Archaeological Areas and Landscape: Case Studies at Kom el Shoqafa, Egypt and Shush, Iran. Sustainability 2017, 9, 572. [CrossRef]

68. Elfadaly, A.; Attia, W.; Lasaponara, R. Monitoring the Environmental Risks Around Medinet Habu and Ramesseum Temple at West Luxor, Egypt, Using Remote Sensing and GIS Techniques. J. Archaeol. Method Theory 2017, 24, 1-24. [CrossRef]

69. Elfadaly, A.; Lasaponara, R.; Murgante, B.; Qelichi, M.M. Cultural Heritage Management Using Analysis of Satellite Images and Advanced GIS Techniques at East Luxor, Egypt and Kangavar, Iran (A Comparison Case Study). In Proceedings of the 17th International Conference Computational Science and Its Applications, Trieste, Italy, 3-6 July 2017; pp. 152-168.

(C) 2017 by the authors. Licensee MDPI, Basel, Switzerland. This article is an open access article distributed under the terms and conditions of the Creative Commons Attribution (CC BY) license (http://creativecommons.org/licenses/by/4.0/). 